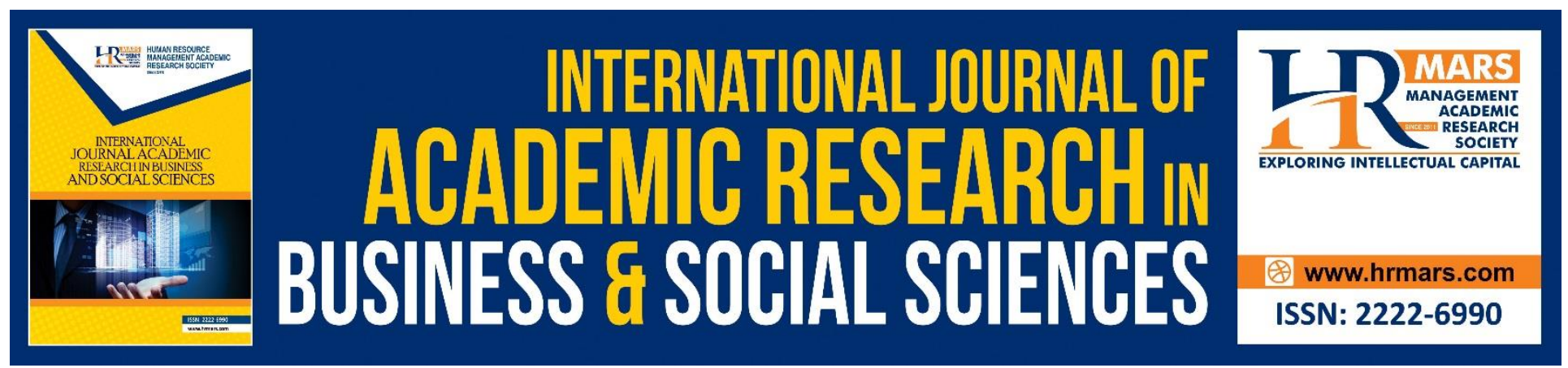

\title{
Learning Literacy Using Augmented Reality (LiTAR): An Application of Learning Through Expository, Social and Technical-Scientific using Augmented Reality as Learning Strategy
}

\section{Noor Aini Binti Ahmad}

To Link this Article: http://dx.doi.org/10.6007/IJARBSS/v8-i11/5353

DOI: $10.6007 /$ IJARBSS/v8-i11/5353

Received: 19 Oct 2018, Revised: 26 Nov 2018, Accepted: 02 Dec 2018

Published Online: 08 Dec 2018

In-Text Citation: (Ahmad, 2018)

To Cite this Article: Ahmad, N. A. B. (2018). Learning Literacy Using Augmented Reality (LiTAR): An Application of Learning Through Expository, Social and Technical-Scientific using Augmented Reality as Learning Strategy. International Journal of Academic Research in Business and Social Sciences, 8(11), 1772-1778.

Copyright: (C) 2018 The Author(s)

Published by Human Resource Management Academic Research Society (www.hrmars.com)

This article is published under the Creative Commons Attribution (CC BY 4.0) license. Anyone may reproduce, distribute, translate and create derivative works of this article (for both commercial and non-commercial purposes), subject to full attribution to the original publication and authors. The full terms of this license may be seen

at: http://creativecommons.org/licences/by/4.0/legalcode

Vol. 8, No. 11, 2018, Pg. 1772 - 1778

http://hrmars.com/index.php/pages/detail/IJARBSS

JOURNAL HOMEPAGE

Full Terms \& Conditions of access and use can be found at http://hrmars.com/index.php/pages/detail/publication-ethics 


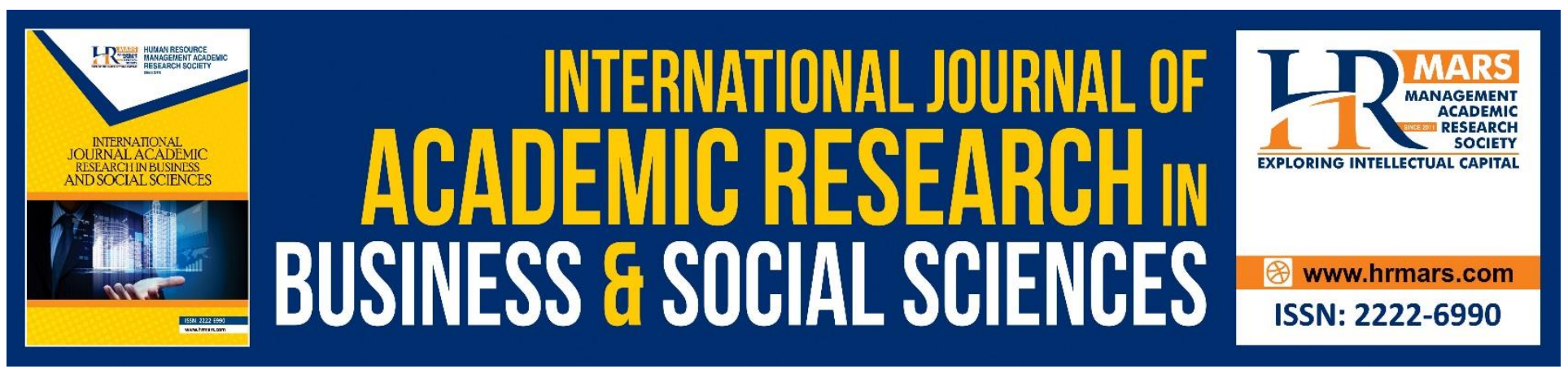

\title{
Learning Literacy Using Augmented Reality (LiTAR): An Application of Learning Through Expository, Social and Technical-Scientific using Augmented Reality as Learning Strategy
}

\author{
Noor Aini Binti Ahmad \\ Universiti Pendidikan Sultan Idris, Malaysia \\ Email: noor.aini@fpm.upsi.edu.my
}

\begin{abstract}
Augmented reality has been used in various ways to support children's learning. This study aims to develop and to test the validity and reliability of the Learning Literacy using Augmented Reality (LitAR) Module as a self-learning strategy for students with special needs, especially the slow learners, students with learning disabilities, remedial students, students in LINUS Program, preschoolers, Orang Asli students and students with low achievement. There were two groups of participant in the study, namely 136 Level One students in eight primary schools in Selangor and Perak were involved in the experimental research and eight expert participants valued the content validity of the module. Experimental study was undertaken for three months period among participants whom comprised seven categories of students, namely students with learning disabilities $(n=22)$, under achiever students ( $n=14)$, remedial students (18), slow learners (16), students in LINUS Program (23), preschoolers (19), dyslexia (16) and Orang Asli students (8). All participants show the characteristics for not mastering reading and writing skills. The findings highlight that in the module content validity, experts agrees that 96.3 percent of the module does not contain any sensitive, negative and subversive elements and two statements shared same percentage of 90 percent on the activities in reading and writing CVCVC words are sufficient, interesting and easy to follow and topics in the modules meet the requirements of teaching reading and writing skills. The findings also show that the LitAR Activity Book's content validity is high at 88.9 with item Lets Color in Activity 1 for CVCV, CVCVCV, CVC and CVCVC scored the highest percentage at 93.8 percent. The findings also show that overall data on content validity by experts on teachers guideline of the module is high at 87.4 percent. In addition, the findings revealed that after using LitAR module during treatment sessions, the score increase with slow learner (95.0), dyslexia (90.2), LINUS Program (86.3), remedial student (74.5), Orang Asli (69.0), learning disabilities (57.3), preschooler (42.6) and low achiever (33.1). This shows that slow learners, dyslexic students, LINUS Program students and remedial students are most
\end{abstract}


prominent among the eight categories of participants after undergoing treatment session using LitAR module. Thus, this study suggests that the LitAR module is most suitable for these four categories of students with special needs to increase their reading skills. It is also recommended that LitAR module to be use nationally as an alternative way to teach reading skills among students with special needs.

\section{INTRODUCTION}

Literacy helps children to think in a more sophisticated ways. Reading make children more aware of language and it helps them to formulate questions and learn about things they did not know (Temple, Ogle, Crawford \& Freppon, 2005). Most of the time, reading comprehension is a crucial skill for academic success of all students. Very often, students with learning disabilities struggle with reading skills and since students learn new information in school by reading; these difficulties often increase the academic struggles students with learning disabilities face (Stetter \& Hughes, 2011). It will cause readers to read slowly and will impact their understanding and reading performances (Rasinski, 2006). Thus, there are many form of effective methods in teaching instructions such as multimedia application, videos and digital games that have been applied into diverse disciplines. The interactive multimedia can be use as effective tool for motivating students to engage in reading activities. It also enhance students' learning motivation and learning performance. We believe that computer-based technology can play an important role in classroom activities as it helps students to be active learners. In this study, we focus in the context of learning reading skills through ICT among students with special needs.

This study aims to develop and to test the validity and reliability of Literacy Module using Augmented Reality (LitAR) as a self-learning strategy for students with special needs, expecially the slow learners, students with learning disabilities, remedial students, Students in LINUS Program, preschoolers, Orang Asli students and students with low achievement.

\section{RESEARCH METHODOLOGY}

Eight primary schools in Perak and Selangor took part in the study. The schools were selected based on a criterion that they provide all five categories of students, students with learning disabilities, under achievers, remedial students, slow learners and Program LINUS. The study was conducted according to the terms laid out in the approval by the Ministry of Education. All treatment sessions were carried out within two hour duration for each categories and were conducted four days per week in a room allocated by the management at each school.

Two of the schools has been selected by the Mualim and Batang Padang District Education officers in order to be their exemplar for SOBILINUS Program in 2017. Both schools were in the same district and one of the school is in rural area while the other is in sub rural area. These criteria will enrich the data collection because researchers are able to look into the usage of the module in both settings. In spite of the modules, research assistants were equipped with smartphones, tablets and lap tops with cameras while collecting data. Three post graduate students were trained to use the module and were paid according to the RMIC rate for enumerator.

Materials included a module that consist of three elements, namely the Teachers Guideline Book, Activity Book and 55 cards. The module is part of Program Sokongan dan Bimbingan material with its tagline Belajar Literasi Menggunakan Augmented Reality or better known as The LitAR. A pre- 
INTERNATIONAL JOURNAL OF ACADEMIC RESEARCH IN BUSINESS AND SOCIAL SCIENCES

Vol. 8, No. 11, Nov, 2018, E-ISSN: 2222-6990 @ 2018 HRMARS

test were given to both group and only participants in the treatment groups will be assist with the module.

\section{LITERATURE REVIEW}

Augmented reality (AR) is a technology that combines virtual objects into the real world and the user can interact with the virtual objects in real time (Azuma, 1997). It also can increase the level of students motivation, positive impact on the learning experience, especially for poor students and assisting in the development of creative thinking, enhance understanding and changing the paradigm of learning curves of students in the study of a subject (Huda Wahida et al. 2010). AR also has the ability of enhancing the real world by using computer-generated information that is projected onto the user's virtual environment. Users can visualize the superimposed information with a selection of display technologies and can interact with it in a natural manner by employing software interfaces, physical markers and hardware interaction devices (Liarokapis, 2012).

Great classroom instruction is not enough. Children who are slow learners have educational needs that require alternative educational interventions and curricular designs. Slow learners tend to function at their cognitive ability, which necessarily means they are significantly below grade level in school tasks (Pears, Kim, Fisher \& Yoerger, 2004). Remedial students are are students who have learning disabilities and dyslexic problems (Rahmah Lob Yussof, Hafiza Abas \& Tengku Nazatul Shima Tengku Paris, 2012). Although response-to-intervention and other remedial strategies may be effective in remedying some skill deficits, there will always be instances in which remedial students need more intensive services (Yaw, Skinner, Orsega, Parkhurst, Booher \& Chambers, 2012). Thus, students with special needs should be given full attention by teachers so they can learn to read and write better. Augmented reality is believed can help them mastering reading skills and it also encourage them to learn literacy.

Poor children in the individual instruction profile fared better than non poor children in that profile; in all other snapshot profiles, poor children fared worse than non poor children (Chien, Howes, Pianta, Ritchie, Bryant, Clifford, Early, Burchinal \& Barbarin, 2010). Specific environmental adaptations and adult interventions that teachers can use in their preschool classrooms to facilitate play that encourages early literacy skills are described (Banerjee, Alsalman \& Alqafari, 2016).

In order to improve the problem-solving skills, communication skills, language skills and many other skills related in education, it is important for learners to be exposed to complex environments. Constructivism might be a broad learning theory because it is synthesized with multiple theories into a single form. Thus it is evident that the method of teaching language skills instruction using technology can be applied with these learning theory.

Thus, learning will be more awesome and awaited rather that scary moment to children. With the use of $A R$, children will be able to connect their real life experience with the words they are trying to spell or read. Engaging them to learn language skills will be more enjoyable if teachers and parents can be with them to explore the world of technology.

\section{FINDINGS}

Table 41: Descriptive Statistic on Augmented Realty to be Used as a Self Learning Strategy within Categories 
INTERNATIONAL JOURNAL OF ACADEMIC RESEARCH IN BUSINESS AND SOCIAL SCIENCES Vol. 8, No. 11, Nov, 2018, E-ISSN: 2222-6990 @ 2018 HRMARS

\begin{tabular}{llcccc}
\hline Categories & & \multicolumn{2}{c}{ Pre-test } & \multicolumn{2}{c}{ Post-test } \\
\cline { 3 - 6 } & & M & (SD) & M & (SD) \\
\hline Slow learner & Treatment group & 52.2 & 10.1 & 95.0 & 9.79 \\
Dyslexia & Treatment group & 54.5 & 7.61 & 90.2 & 5.28 \\
LINUS Program & Treatment group & 58.7 & 17.3 & 86.3 & 13.8 \\
Remedial student & Treatment group & 41.5 & 10.4 & 74.5 & 11.8 \\
Orang Asli & Treatment group & 43.5 & 31.9 & 69.0 & 25.6 \\
Learning disabilities & Treatment group & 35.5 & 25.6 & 57.3 & 24.7 \\
\cline { 2 - 5 } Pre-schooler & Treatment group & 17.3 & 17.2 & 42.6 & 18.4 \\
Low Achiever & Treatment group & 14.0 & 7.57 & 33.1 & 9.97
\end{tabular}

Table 1 which focus on the suitability of augmented realty as a self learning strategy for students with dyslexia, slow learners, low achievers, Orang Asli students, LINUS program students, remedial students, pre-schoolers and students with learning disabilities. Table shows that after using LitAR module during treatment sessions, mean score within categories in the post-test were slow learner (95.0), dyslexia (90.2), LINUS Program (86.3), remedial student (74.5), Orang Asli (69.0), learning disabilities (57.3), preschooler (42.6) and low achiever (33.1). This shows that slow learners, dyslexic students, LINUS Program students and remedial students are most prominent among the eight categories of participants after undergoing treatment session using LitAR module. Thus, the module is most suitable for these four categories of students with special needs compare to the balance four categories in this study, namely Orang Asli students, students with learning disabilities,

pre-schoolers and low achievers.

\section{CONCLUSION}

Despite the impact of the ICT as demonstrated in previous research, in this study it shows a vice versa result. There was no significant relationship between ICT and literacy skills in the preschooler and Orang Asli groups. The findings of this study showed that there could be a couple of explanations to this finding. Students in rural areas might not be self directed in acquiring knowledge and skills need to be teach for them to use gadgets. Or it could be perceive that the awareness towards ICT is still at low level among the Orang Asli students.

Thus, the results imply that generally students with special needs in rural areas do not have the ability and confidence to use smartphone or gadgets and they are not self directed in terms of the usage of computers. This outcomes could also perhaps mean some great news to the policy makers in their pursuit towards having more students to use smart applications. We are now moving 
the an era where all students should have the ability to use the technology found in computer without having to depend on teachers or friends or siblings and others for them to utilize the technology.

We also found that their deficit in reading skills make them vulnerable or at risk of several psychological problems which could be addressed by incorporating interventional teaching strategies. One of the solution is by using $A R$ as teaching and learning technique. The following discussion will focus on the nature and strength between traditional technique and AR application. In this study, it was identified that there was significant result between both techniques. However, in comparison in doing so, it helps to identify to what extent technology acceptance among teachers will influence reading and writing skills among students with special needs.

The mean difference for students in treatment group of LINUS Program (17.1) and learning disabilities (14.0) is rather high but this is not surprising and it could be influence by several factors and the most important of them all is the use of augmented reality application in learning reading skills. They also showed their feeling and attitudes of favorableness and unfavorableness towards the process in learning reading skills. They seem passive when were asked to read the words in the activity book but their attitude change immediately when they used the LitAR cards. Moreover based on the study, it can be construed that students who viewed the 3D cards were able to demonstrate better understanding in reading and they also integrate knowledge and skills they learn in classroom to elsewhere. It coincides with previous findings of other researchers that ICT can be identified as an apparent dominance to read and write among students.

It is also note worthy that this study was conducted in rural and semi rural primary schools where most schools were equipped with computers. Furthermore, most teachers and children are also provided with lap-tops to encourage the computer usage in the teaching-learning process. While most students used to use phones in their daily life and due to these reasons that participants were experiencing moderate levels in terms of usage capability of the LitAR cards.

\section{Acknowledgement}

This work was supported by The Ministry of Higher Education, Universiti Pendidikan Sultan Idris (UPSI), the Research Management and Innovation Centre of UPSI and the Faculty of Education and Human Development, UPSI.

[Fundamental Research Grant Scheme: 2014-0112-106-012].

\section{Corresponding Author}

Assoc. Prof. Dr. Noor Aini Ahmad

Special Education Department

Faculty of Human Development

Universiti Pendidikan Sultan Idris, Malaysia.

35900 Tanjong Malim

Perak, Malaysia

Email: noor.aini@fpm.upsi.edu.my 
INTERNATIONAL JOURNAL OF ACADEMIC RESEARCH IN BUSINESS AND SOCIAL SCIENCES

Vol. 8, No. 11, Nov, 2018, E-ISSN: 2222-6990 (C) 2018 HRMARS

\section{References}

Azuma, R, T. (1997). A survey of augmented reality. Presence: Teleoperators and Virtual Environments 6, 4 (August 1997), 355-385. Cambridge, MA: The MIT Press.

Banerjee, R., Alsalman, A. \& Alqafari, S. (2016). Supporting sociodramatic play in preschools to promote language and literacy skills of English Language learners. Early Childhood Education Journal, 44: 299-305.

Chien, N, C., Howes, C., Pianta, R, C., Ritchie, S., Bryant, D, M., Clifford, R. M., Early, D. M., Burchinal, M. \& Barbarin, D. M. (2010). Children's classroom engagement and school readiness gains in prekindergarten. Child Development, 81(5): 1534-1549.

Liarokapis, F. (2012). Augmented reality interface for assisting computer games university students. Bulletin of the IEEE Technical Committee on Learning Technology, 14(4): 7-10.

Pears, K.C., Kim, H.K., Fisher, P.A. \& Yoerger, K. (2016). Increasing pre-kindergarten early literacy skills in children with developmental disabilities and delays. Journal of School Psychology, 57: 1527.

Rasinski, T. (2006). Reading fluency instruction: moving beyond accuracy, automaticity and prosody. The Reading Teacher, 59(7): 704-706.

Stetter, M.E. \& Hughes, M.T. (2011). Computer assisted instruction to promote comprehension in students with learning disabilities. International journal of special education 26(1): 88-100.

Temple, C., Ogle, D., Crawford, A. \& Freppon, P. (2005). All Children Read: Teaching for Literacy in Diverse Classrooms. New York: Addison Wesley Longman.

Yaw, J., Skinner, C. H., Orsega, M.C., Parkhurst, J., Booher, J., \& Chambers, K. (2012). Evaluating a computer-based sight-word reading intervention in a student with intellectual disabilities. Journal of Applied School Psychology, 28, 354-366. 